\section{1. わが国の製紙工業の現況}

わが国の紙パルプ産業の現状を端的にとらえるために は，日本製紙連合会が刊行している広報紙「紙・パル プ」の 1990 年特集号を見ることがもっともわかりやす い。ここでは毎年 1 回「紙パルプ産業の現状」の表題の もとに前年度の動向をわかりやすく解説し, われわれ専 閒家の基礎資料としてまた紙パルプ関連業界の情報源と して大きな役割を果たしている。ここではまず，この特 集号から主要な項目を拔粋して紙・パルプ産業の概要を 抎伝光したい。

平成元年度に和けるわが国の紙・板紙の需要は極めて 活発であり，前年度比で 9 パーセント近い伸びを記録し 約 2,700 万トンに達して抒り, 国民 1 人当たり年間約 $220 \mathrm{~kg}$ の紙・板紙を使ったことになる。これは総量的 には米国の約 7,000 万トンに次いで世界第 2 位，1人 当たり消費量といら点でも米国の約 $310 \mathrm{~kg}$ には及ばな いが世界上位に位置している。

わが国の紙パルプ産業の特徵は原木は別として国内生 産, 国内消費の形をとり続けていることであるが，最近 になってその傾向が变化し紙・板紙の輸出は前年度比 15 パーセントと減少し一方, 輸入は約 $13 \%$ の増加を示し この状況はここ数年続いている。しかし, 両者之も総量 的には影響が少ないと見なされている。

これに対して紙・板紙の原料で㐫る木材について注, 約 1 億 $\mathrm{m}^{3}$ のうち 70 パーセント（含輸入パルプ 10 ハ 一セント) が海外依存し，米国，カナダ，オーストラ リアなどから大半がチップ状で輸入されている。この中 で最近環境問題で話題となっている熱帯雨林については 数パーセント未満が使われているに過ぎない。

\footnotetext{
平成 3.1 .8 受理

Trends of Paper Industry

Takashi KAdoya

* 神奈川大学理学部応用生物科学科

平塚市土屋 2946 (宁259-12)
}

また，製紙用パルプの輸入は年々上昇して抒り，約 300 万トンと前年度比で $10 \%$ 強の増加でわが国パルプ 消費量の約 $22 \%$ を占めている。

わが国の製紙用原料として特記すべき点に紙のリサイ クルがある。現在わが国で使われている紙・板紙の約半 分が回收, 再生産され, この量は全製紙原料の約 50 パ 一セント達する。ここ数年資源, 環境問題の意識の高 まりとともに紙のリサイクル技術は長足の進歩を示し， 貴重な製紙原料として従来にも増して使用されてきた。 最近の新聞の $\mathrm{PR}$ 記事に以下のような記事が揭載され ている。「古緍の利用は年々盛んになっています。この 新聞紙約 40 パーセントが再生紙でつくられていま す。コミック紙やちり紙などはもうすでに 100 パーセン ト。トイレットペーパーや段ボールは約 90 パーセン ト。私たちの身近なところに再生紙がどんぞん利用され るよらになってきました。いままで再生紙では難しかっ た OA 用紙, デパートの紙袋、コーテット用紙などにも その利用範囲を広げています。……」

このようなリサイクル化に続く最近の動向としては㪕 量化がある。

製紙産業の 1 つの柱である新聞用紙はかつて良質の木 材と大量のエネルギーを消費する紙であった。この紙の 重量 (科量) という点では昭和 50 年 (1975 年) の時点 で $52 \mathrm{~g} / \mathrm{m}^{2}$ が標準でめったが除々に軽量化が進み, 平成 元年 (1989 年) には $46 \mathrm{~g} / \mathrm{m}^{2}$ となり, いまや第 3 次軽

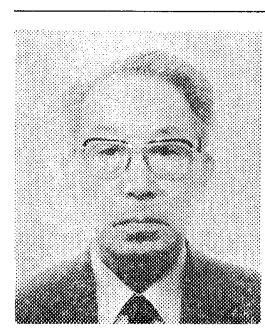

[氏名】かどや たかし

[現職] 神奈川大学理学部応用生物科 学科教授

[趣味】テニス, ゴルフ,ドライブ

[経歷]昭和 24 年東北大学理学部物理 学科卒, 昭和 24 年 昭和 47 年 国策パルプ工業(株)中央研究 所, 昭和 47 年 昭和 59 年 、東 京大学農学部教授, 昭和 59 年 ～平成元年千葉大学工学部客 員教授, 平成 2 年 現職 
量化の時代に入り $43 \mathrm{~g} / \mathrm{m}^{2}$ と実に $17 \%$ 以上の減量へと 進んでいる。これによる省資源的役割は莫大なものとな る。この社会的背景として海外品との競合, 印刷様式の 変化, 輸送コストの低減, 増頁への対応など様々な要因 がありこれに答えて製紙技術（原料処理，新抄紙技術， 品質の均一性など)，印刷技術（インキ，製版など）が対 応したことによるものである。

紙の用途の一方の主力品である段ボール用紙もかつて $190 \mathrm{~g} / \mathrm{m}^{2}$ が圧倒的に多かったが昭和 59 年 (1984 年) には $170 \mathrm{~g} / \mathrm{m}^{2}$ が主流となり $20 \mathrm{~g} / \mathrm{m}^{2}$ の軽量化が進んで いる。製紙原料の品質が低下している中で，これだけの 軽量化が達成できたのは製紙技術の進歩と段ボール製造 設備の革新, 製箱技術の改善, 物流の合理化など総合技 術の進歩によるものである。

かつて, 重い紙の代表的品種であったアート紙も塗工 量が約半分に近いコート紙へと移行し,ささらに原紙の軽 量化に加えて塗工量の軽量化が前進し最近では微狳工印 刷紙と称する新品種が登場してきている。

製紙工業の活性化につながる要目としてさらに情報用 紙がある。新しい情報化時代の幕明けとともに情報用紙 が，ディスプレイの大きな役割を果たすことはすでに予 測されていたが昨今の情報機器の爆発的な伸びによって 情報用紙之称する品種の急成長は目覚ましいものが少る。 現在, 約 20 種類にも及ぶ情報用紙が社会の到るとこ ろで使われ, 量的には約 140 万トン/年, 年率 14 パー セント近い急成長製品となって拈り，この伸びが紙パル プ産業へ及淮す影響力は極めて大きい。

以上極めて簡単に紙パルプ産業の実情をまとめてみ た。紙・板紙工業は鉄やセメントと同じように素材産業 の 1 つと見なされ，㐫まり变貌の少ない分野とされてい るが，ここに示した事例のように時代の変化に呼応しか つ先取りしながら国の基幹産業としての役割を果たして おり，紙・板紙の機能を代替するものが現われない限 り 21 世紀も存続して行くものと考光られる。

\section{2. 紙 の 本 質}

紙という材料愊 $20 \sim 40 \mu \mathrm{m}$, 長さ 1 3 mm, 厚さ数 $\mu \mathrm{m}$ の主として木材パルプ䋐維が 10 本から 100 本層状 に重なり繊維相互が絡み合いその一部は結合してシート 状を構成し, かつその構成中に薬品や数 $\mu \mathrm{m}$ の填料が加 わって出来上がっている薄層体である。これらの繊維が 積層して出来上がる過程での条件によって軟らかいティ ッシュペーパーや紙タオルのようなものから，いわゆる 印刷・筆記用の紙, さらには板紙や建材などの硬質な材 料まで造り出せる。また，種々な加工を施すことによっ
て, カップ, トレー, 箱状の容器となり, 表面を処理す ることによって，印画紙，コート紙あるいはハードコピ 一の不可欠なメディアとして情報用紙などが造り出され る。このように，紙の用途は個々に数光げて見ると数

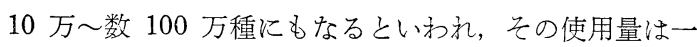
国の文化の尺度とさえいわれている。

このように，紙が広く世の中で使われている理由は数 多くあるが，やはり大量に安くどこでも手に入り，乙か も他の材料にない独自の性質と機能を持っているからで あると考えられる。

紙の用途を大別すると情報を記録し保存する，ものを 包㕛保護する，液体を拭きとる，吸いとるといわれて物 るがさらに最近の社会構造の变化沁応じて前述の情報記 録紙, フィルター材料, 電気材料から瓶, 缶, 皿の代替 品やインテリア，建材の一部などの従来の紙の概念を超 えた用途が増え続けている。

このような紙の本質を理解するには紙を構成している 単繊維の特性と, これら単繊維で構成されるマトリック スとの関係を理解せねばならない。このよらな単繊維と マトリックスとの関係は古くから数多くの研究が行わ机

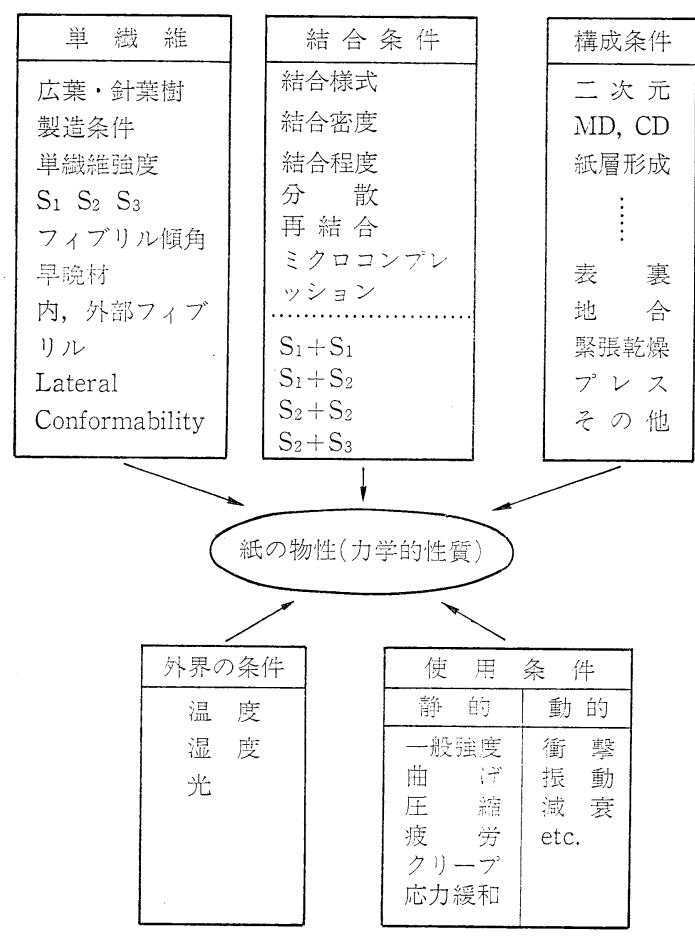

$\mathrm{S}_{1}$; 二次壁外層 Lateral Conformability; 横方向の柔乾性 $\mathrm{S}_{2}$; 二次壁中層 $\mathrm{MD}$; 抄紙方向

$\mathrm{S}_{3} ;$ 二 二次壁内層 $\mathrm{CD}$; 横方向

図-1紙の物性に及ぼす種々の因子 


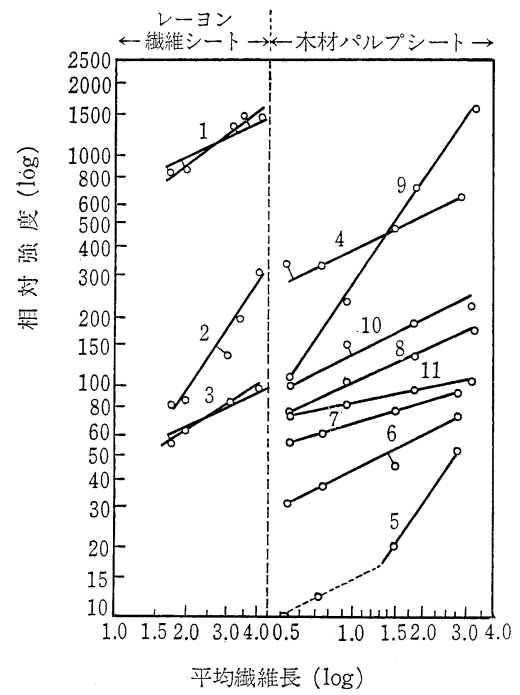

1. 引張強さ (レーヨン繊維)

2. 引裂強さ ( $"$ )

3. 剛さ ( $"$ (未)

4. 引張強さ (未吒解パルプ)

5. 引裂強さ (

6. 剛さ

7. ゼロスパン強さ ( $\quad$ "

8. 引張強さ (叮解パルプ)

9. 引裂強さ (

10. 用さ (

11. ゼロスパス強さ（"

図-2 シート構成繊維の長さとシート強度の関係

ているが，最近では木材パルプに加えて種々の合成繊 維, 無機繊維, 金属繊維などの非木材繊維とを混抄して 新しい機能を求めた紙が出現し, 紙の本質はかなり複雑 となってきた。

基本的には木材パルプ繊維とそれで構成された紙との 物性は図-1 のよらな形でまとめられる1”。紙の性質はま ずこれる構成するパルプ纎維で決まり，広葉樹か針葉樹 の繊維の長さ, パルプ材から繊維をとり出す条件, 製紙 に到るまでの繊維が受ける種々の処理条件が大きく影響 する。

図-2 左はモデル繊維として長さ $1.5 \mathrm{~mm}$ から 4.0 $\mathrm{mm}$ のレーヨン繊維を用いてシートを作成しその強度を 求めたものである。ただし, 繊維間の結合は特殊な接着 剂を用いている。図右半は木材パルプ繊維を篩分けした 原料を用いて抄いた紙の繊維長とシート強度との関係を 示守 ${ }^{2)}$ 。繊維長約 $0.5 \sim 1.0 \mathrm{~mm}$ 程度は大体広葉樹材加 のパルプ繊維であり, $1.0 \mathrm{~mm} \sim 3.0 \mathrm{~mm}$ 程度が針葉樹材 パルプ繊維である。また, 未印解, 吒解とは水中で繊維
を機械的に処理をし繊維の形態と機能を変えたものであ る。

レーヨン繊維と同じく紙の強度的性質は繊維の長さに よって変わり, また吒解の程度によって変わることが図 からわかる。極めて大雑ぱではあるが繊維の長さ $L$ と得 られたシートの密度 $d$ が紙の物性值に及ぼす関係は

$$
\begin{aligned}
& \text { 裂断長 }(\mathrm{km})= \frac{\text { 引試験片の幅 }(\mathrm{mm}) \times \text { 試験片の坪量 }\left(\mathrm{g} / \mathrm{m}^{2}\right)}{} \\
& \times 100=k_{3} d \cdot L^{0.5} \\
& \text { 比破裂強さ }= \frac{\text { 破裂強さ }\left(\mathrm{kgf} / \mathrm{cm}^{2}\right)}{\text { 坪量 }\left(\mathrm{g} / \mathrm{m}^{2}\right)} \times 100=k_{2} d \cdot L \quad(2) \\
& \text { 比引裂強さ }= \frac{\text { 引裂強さ }}{\text { 坪量 }}= \pm k_{4} L^{1.5} / d \\
& \text { 剛性率 }=\frac{\text { 曲げこわさ }}{\text { 坪量 }} k, d^{0.5} \cdot L^{0.5} \\
& \text { 吸収性 }=k_{5} / d
\end{aligned}
$$

といら式が提案されている。

(但し $k_{1}, k_{2}, k_{3}, k_{4}, k_{5}$ はパルプの種類, その処理法 で決る定数)

このように紙の性質には繊維の長さと吒解といら操作 による繊維同志の結合の程度が大きく影響する。

図-3 は紙の表面の拡大写真であり, 左図のマークの 部分を 10 倍に拡大すると右眓のようになる3。 これを 見るとリボン状の繊維がお互いに交差し糊で貼り合わさ れたよらに見える。この部分は繊維表面同志で結合が起 きていると考えられ，この結合の程度は紙の性質を支配 する役割を果たしているとされている。結合の程度は前 述の吒解といら操作によってほとんど決まり操作時の水 の性質, 温度, パルプの種類や濃度, 操作機械の構造と 操作條件などが関与する極めて複雑な機構によるもので, 詳細は成書を参照されたい4。

また, 図-3 を見ると一見平滑に見える紙の表面は, 意 外と粗雑であり一部には空洞があるのがわかる。

紙の表面は筆記, 印刷, 複写などの作業に対して極め て重要であり一般に平滑度といら尺度で示されるが, こ れと凹凹を示す表面粗さとの関係を各種用紙と印字方式 によって一覽すると表-1 のようになる5)。これより, 表 面を何らかの方式で加工しない限りは表面の粗さには限 度があり, 印刷の様式が進歩し画像が繊細になるに従っ て紙面を他の方法で処理する必要が生じ, ニート紙, ア ート紙などが出現している。

また, 紙面の空洞は表面粗さにも関連するが紙を貫通 する細孔も含まれ液体を吸いとる拭きとる性質に影響す る。

これは紙を構成するセルロース繊維の優れた対接着特 性（表面自由エネルギー特性）と相まって紙の大きな特 徵である。 


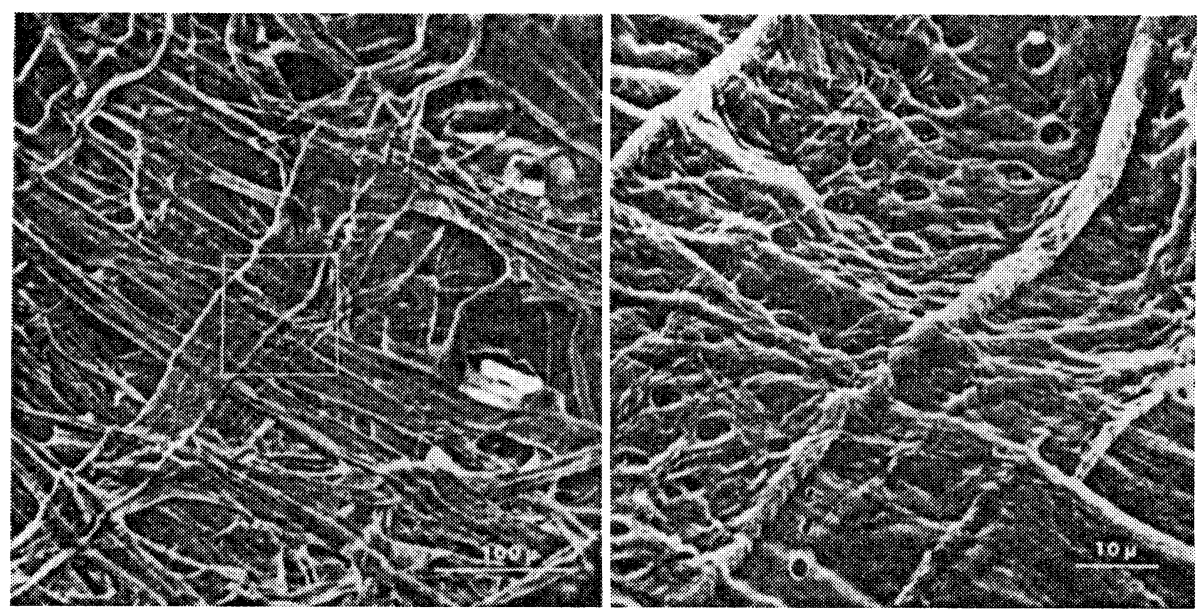

図-3 紙の表面の電顕写真

表-1 インキ皮膜厚み，印圧，用紙特性

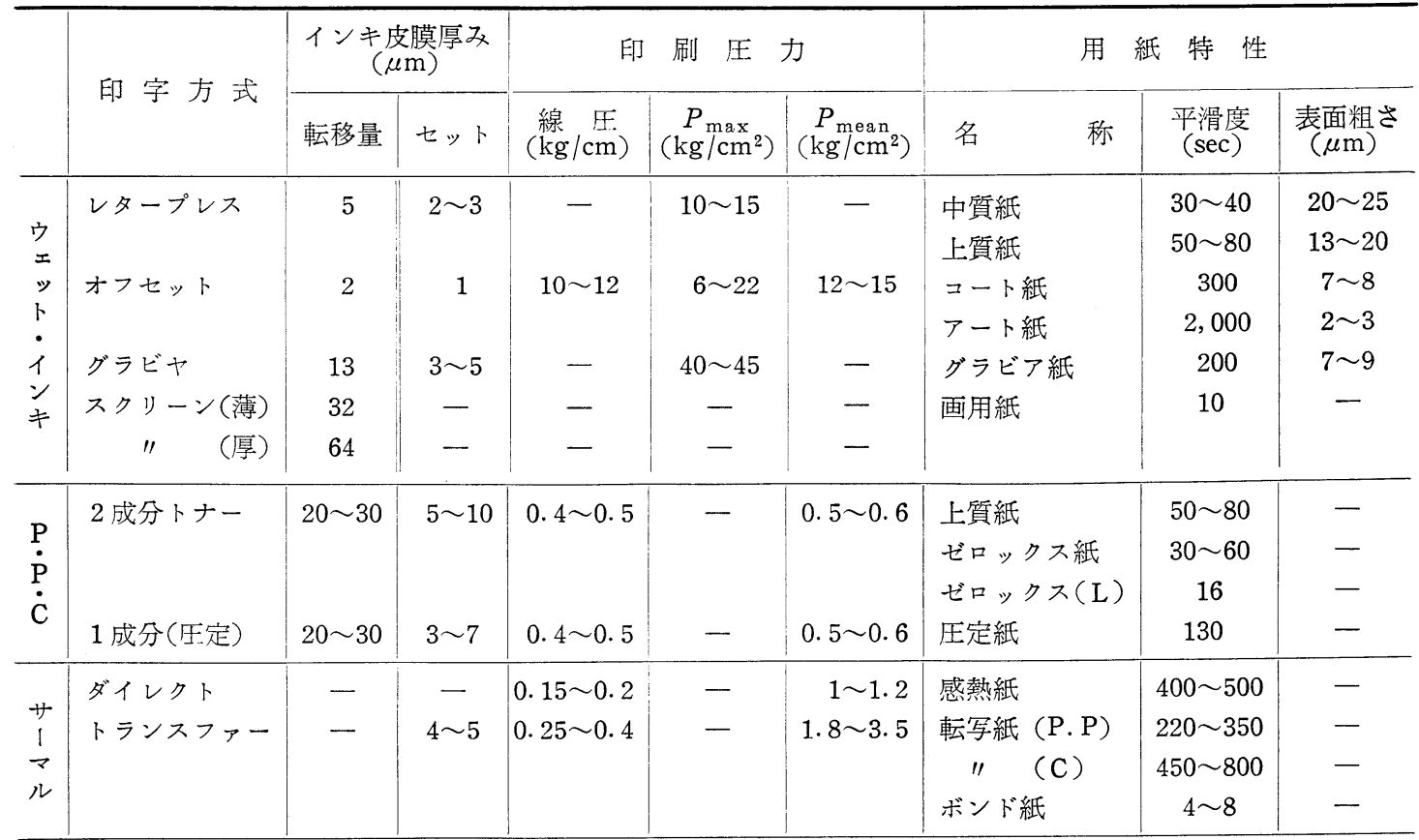

注）ゼロックス紙：(北米用), ゼロックス (L) : 北米レター用紙, 転写紙 (P.P.C)：プレーンペーパー，コヒア， (C) : コート紙

表-2 紙の密度と空隙率

\begin{tabular}{c|c|c}
\hline & 密度 $\left(\mathrm{JIS}\right.$ 法) $\left(\mathrm{g} / \mathrm{cm}^{3}\right)$ & 空隙率\% \\
\hline グ ラ シ ン 紙 & 1.10 & 26 \\
上 質 紙 & $0.60 \sim 0.85$ & $61 \sim 45$ \\
ラ フト 紙 & 0.60 & 59 \\
新 聞 用 紙 & 0.57 & 61 \\
含浸加工用原紙 & $0.40 \sim 0.60$ & $73 \sim 60$ \\
\hline
\end{tabular}

紙の中に細孔がどれだけ含まれているかは特殊な方法 で求めねばならないが, 一般には空隙率あるいは透気度 という尺度で判断されている。また紙の密度と空隙率と は式（6）で示されるよらな関係があり, 表-2に各種の 紙の密度と空隙率の值を示した。

$$
\text { 空隙率 }=1-\frac{\text { 紙の密度 }}{\text { 紙を構成する材料の密度 }} \times 100
$$

これを見ると特殊な紙を除いて空陌率は 40～60\% に 
表-3 紙の性質を支配する重要因子と機能

\begin{tabular}{|c|c|c|c|c|c|c|}
\hline & 紙の性質 & $\begin{array}{l}\text { 長所 }{ }^{\circ}, \text { 短所 }{ }^{x} \\
\text { (他の }\end{array}$ & & $\begin{array}{l}\text { 長所 } \\
\text { 法 }\end{array}$ & & 用 \\
\hline & & & & achine & off machine & \\
\hline 力 & 乾燥強度 & 適度に & (1)セルロース分子 & 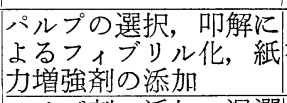 & E補強 & $\begin{array}{l}\text { 包装紙全般, 積層板, } \\
\text { 化粧板 }\end{array}$ \\
\hline 的 & 湿潤強度 & 弱い× & $\begin{array}{l}\text { (2)単繊維自体の強 } \\
\text { (3)繊維のすべりに. }\end{array}$ & 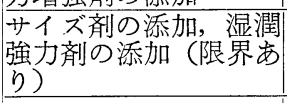 & 同上 & $\begin{array}{l}\text { 紙タオル, ティーテ゚ッッ } \\
\text { ク, 水系塗工厚紙 }\end{array}$ \\
\hline 性 & 剛性 & 嫖が軟性いな & $\begin{array}{c}5 \text { 破断への摩 } \\
\text { 擦抵抗 }\end{array}$ & $\begin{array}{l}\text { ヘルプの選択 (リンタ } \\
\text { 一他), 媜料の添加 }\end{array}$ & 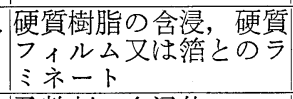 & 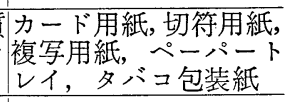 \\
\hline & 塑性・変形 & 比較! & $\begin{array}{l}\text { (4)纎維間結合の強 } \\
\text { さと数 }\end{array}$ & ペルプの選択他 & 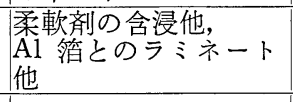 & $\begin{array}{l}\text { その他折りたたみ性が } \\
\text { 必要な途 }\end{array}$ \\
\hline & $\begin{array}{l}\text { 寸法 } \\
\text { 接 } \\
\text { ル }\end{array}$ & 湿後変 & $\begin{array}{l}\text { (1)セル更性 OH 基の存 } \\
\text { 在 }\end{array}$ & 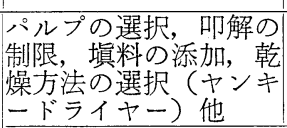 & 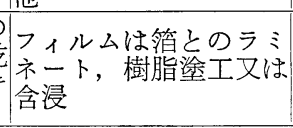 & $\begin{array}{l}\text { 地図用紙, 各種記録紙, } \\
\text { 粘着紙, 㔀離紙, 等加 } \\
\text { 工紙全般 }\end{array}$ \\
\hline & 防湿(水)性 & 生不良 ${ }^{x}$ & $\begin{array}{l}\text { (2)木材䕙維の形態 } \\
\text { 学的梏造 }\end{array}$ & サイズ剤の使用 & 同上 & $\begin{array}{l}\text { 各種包装紙 (PVDC塗 } \\
\text { 紙, ワックス紙他) }\end{array}$ \\
\hline 筟 & 吸湿(水)性 & 良 ${ }^{\circ}$ & $\begin{array}{l}\text { (3)緘維集合体の構 } \\
\text { 兑 }\end{array}$ & $\begin{array}{l}\text { ジルプの選択，サイズ } \\
\text { 剤の制限他 }\end{array}$ & 吸湿剂 & 紙タオル, 紙オムツ \\
\hline 造 & 耐油 & 吸油悄 & & 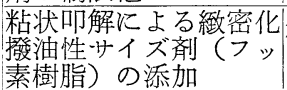 & 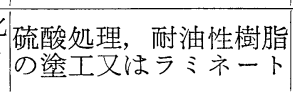 & $\begin{array}{l}\text { パーチメント紙, } \\
\text { シン紙, 耐油紙 }\end{array}$ \\
\hline $\begin{array}{l}\text { 門 } \\
\text { 等 }\end{array}$ & 多 孔 性 & 通気性, 含浸性 & & $\begin{array}{l}\text { 制限他の選択, 叨解の } \\
\end{array}$ & & 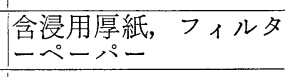 \\
\hline 亭 & $\begin{array}{l}\text { ガスバリ十 } \\
\text { 性 }\end{array}$ & 低い× & & $\begin{array}{l}\text { サイズプレス加工の強 } \\
\text { 化等 (限度あり) }\end{array}$ & $\begin{array}{l}\text { 䬦りア性ある材料との } \\
\text { 複合 }\end{array}$ & 保香紙, 食品包装紙 \\
\hline & 反応性 & 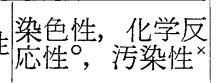 & & & & 有機溶剤系塗工用厚紙 \\
\hline & 不透明性 & E高い。 & & 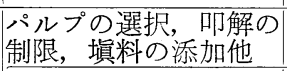 & $\begin{array}{l}\text { 顔料塗工, A1 箱のラ゙.着他 } \\
\end{array}$ & 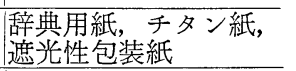 \\
\hline $\begin{array}{l}\text { 光 } \\
\text { 学 }\end{array}$ & 透 明 & E低い× & (2)繊維集合体と乙 & $\begin{array}{l}\text { 同上, 叮解, プレス, } \\
\text { カレンダ強化他 }\end{array}$ & $\begin{array}{l}\text { セルロースの屈折率に } \\
\text { 近い材料の含浸 }\end{array}$ & $\begin{array}{l}\text { トレーシングペーパ } \\
\text { ラ゙ン第2原図用紙, グ } \\
\text { ラシン紙 }\end{array}$ \\
\hline 的 & & ?低い× & $\begin{array}{l}\text { ての紙層中の空 } \\
\text { 気 }\end{array}$ & $\begin{array}{l}\text { カレソダ強化, 媜料の } \\
\text { 添加, オマシンー } \\
\text { 卜 }\end{array}$ & 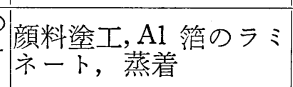 & $\begin{array}{l}\text { 印刷コート紙, 金属光 } \\
\text { 沢紙, 豊色紙 }\end{array}$ \\
\hline 質 & 色 & 黄色味带 & & 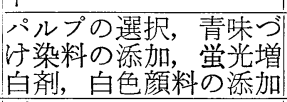 & & 同上 \\
\hline 表 & 平 滑 & 低 & $\begin{array}{l}\text { (1)水の存在下に特 } \\
\text { 特る緎維集合体 }\end{array}$ & 炛他ス, カレンダの強 & 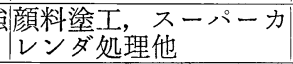 & 同上㔀離紙, 工程紙 \\
\hline 性 & 接 着 性 & E良い。 & $\begin{array}{l}\text { 9形成 } \\
\text { (2) セルロ繊維 }\end{array}$ & & \begin{tabular}{|l|} 
接着増進プライマーのー処理他 \\
等
\end{tabular} & $\begin{array}{l}\text { 各種塗工紙, ラミネー } \\
\text { 紙の基材 }\end{array}$ \\
\hline 筫 & 表面强 & 低い, & $\zeta$ & $\begin{array}{l}\text { サイズブ剤の強化，サイ } \\
\text { ブス加 }\end{array}$ & 樹脂塗工 & 印刷用紙 \\
\hline 熱 & 耐熱(寒)性 & 良い。 & 儈造 & \begin{tabular}{|l|}
$\mid$ 無機材料, 耐熱性高分 \\
材料の利用
\end{tabular} & \begin{tabular}{|l|} 
シアフコチル化などの \\
化学処理他
\end{tabular} & 耐熱絶縁紙 \\
\hline $\begin{array}{l}\text { 的 } \\
\text { 性 }\end{array}$ & 然 焼 性 & Eあり× & \begin{tabular}{|l|} 
極性基として $\mathrm{OH}$ \\
基を゙, 2 回 \\
\end{tabular} & 同上, および難燃剤の & |同上，特よび難燃剤の & $\begin{array}{l}\text { 難燃壁紙, 防炎紙, 裏 } \\
\text { 糽吉紙 }\end{array}$ \\
\hline 質 & $\begin{array}{l}\text { 熱可塑性 } \\
\text { (ヒート性) }\end{array}$ & なしメ & $\mid$ & $\begin{array}{l}\text { 合成パルプの混抄, 熱 } \\
\text { 化性樹脂のカプセル }\end{array}$ & 熱可塑性樹脂の塗工又 & 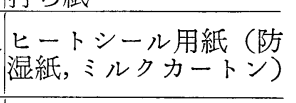 \\
\hline 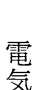 & 電気絶縁性 & 生比較的西り。 & & $\begin{array}{l}\text { ゚イプの選択, 脱イオ } \\
\text { ン水の使他 }\end{array}$ & 絶縁樹脂の含浸 & \begin{tabular}{|l} 
電気絶縁紙 (ニンデン \\
績層板
\end{tabular} \\
\hline 的 & 導 電 & 尘なじ & $\prime \prime$ & $\begin{array}{l}\text { 導電性樹脂, カーボン } \\
\text { ブラッグ添加 }\end{array}$ & 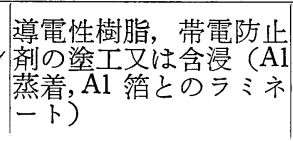 & $\begin{array}{l}\text { 電気感応記録紙(静電, } \\
\text { 放電, } \\
\text { 雱止紙 }\end{array}$ \\
\hline
\end{tabular}


表-4 昭和 63 年改正通産省紙パルプ統計分類(紙)

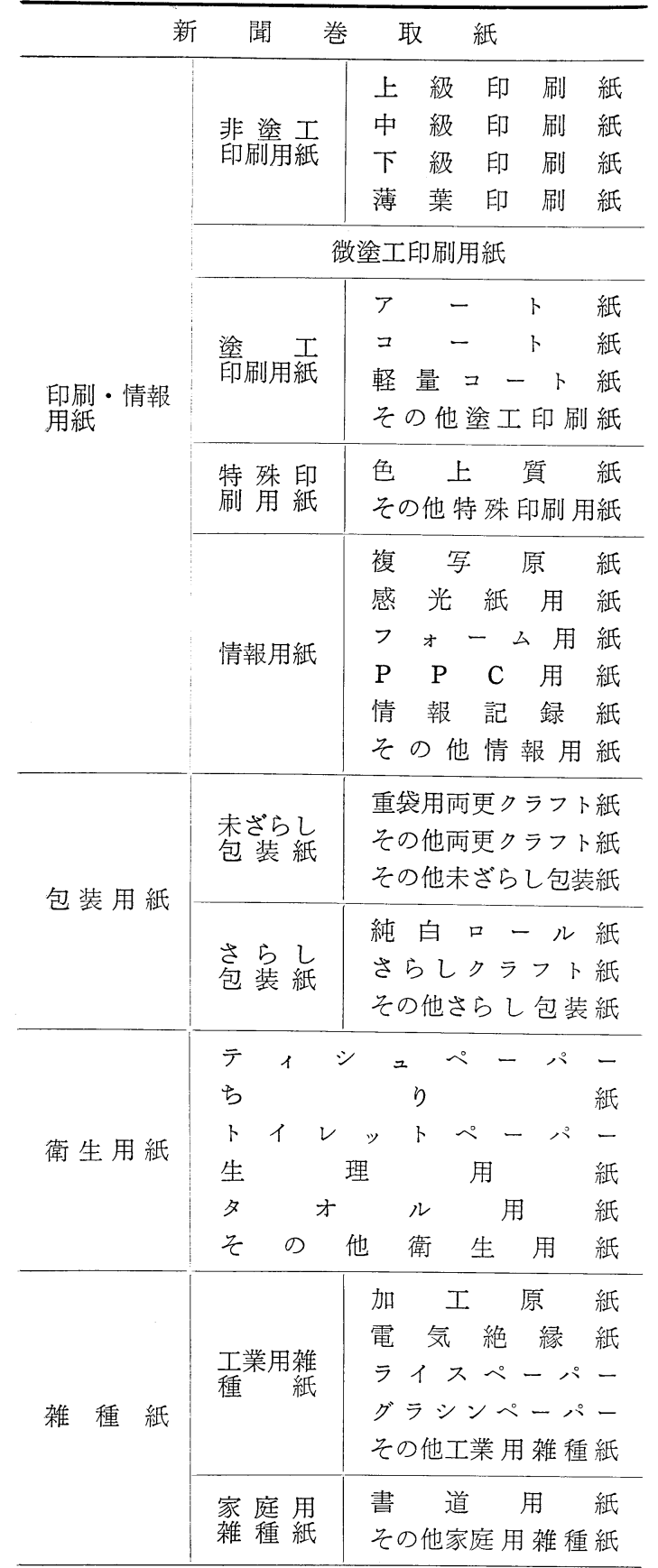

もなり, 紙の半分は空気を含んでいるともい光, これが 紙の白さや不透明性, 熱伝導性, 吸液性などに関連して いる。

このように，木材パルプという1つの原料を処理する
ことによって様々な特性や用途が生まれ，これを理解す るには別途専書を参照されたい、,7)。

以上の事項をふま兄て表-3 は紙の性質を支配する重 要因子と機能といら観点からまとめられたもので, 専門 用語について理解し難いところがあると思われるが体形 化されたものとしてここに示すことにする8)。

\section{3. 紙の種類と用途}

紙の種類と用途については表-3 飞も示されているが， 昭和 63 年 (1988 年) 大幅な改正が行われた紙パルプ統 計分類を表-4 に示す。

本表は昭和 43 年以来通産省などで用いられてきた統 計分類が時代に即応しなくなったため 20 年ぶりに改正 されたもので，以前印刷・筆記図画用紙といった項目が 印刷・情報用紙という新名称となり, 従来薄葉紙拈よび 雑種紙の中に散在していた各種情報用紙を統合し新たな 枠を設けている。また，印刷用紙中の微塗工印刷用紙と いう枠も新た沉認知されている。このことは，ここ数年 の情報産業の急進に伴い種々の情報用紙が出現し量的な 面でも地位を確保したことを意味し，かつてオフィスの ペーパーレス化という予測が覆えったことを示すもので ある。また, 微塗工印刷用紙についても省資源, 省エネ ルギーの要求と軽薄短小で高機能性の要求に応じて出現 したもので，時代の波が紙の新分野に反映した $1 つ の$ 事 例として受け止められる。

な特，板紙の分野についての改正は行われなかったの でここでは割愛する。

さて，表-4 中の印刷・情報用紙拉よび新聞用紙は本 誌とは極めて関係の深い分野であるが，情報用紙につい ては別途企画されておるのでここでは印刷用紙の状況 について多少紙数を割いて見たい。

紙は情報の媒体として古くから使われているが，中で も広告という点では図-4 のように約 44\% 之電波関係を 上回る比率を有し, 新聞による広告の効果は不変の地位 にあることがわかる。李た, 雑誌, DM, 折込の用紙と して最近上質紙化かわって塗工紙が急成長を遂げて抒 り，表-5 汇示すようにポスター，パンフレット，カタロ グ, カレンダー, チラシのようないわゆる商業印刷が書 籍, 雑誌のような出版印刷より量的比率が高くかつ急成 長していることがわかる。

このような動向を反映して塗工紙の生産量性平成元年 度 358 万トンと前年度比 $20 \%$ 強の増加を示し, 紙・板 紙の増加率 9\% をはるかに超觉ている9\%。质の内訳は 図-5 に示すように A 2 グレードの軽量コート紙が需要 の半分近くを占め, MC (微塗工紙) 紙がそれに次いで 
表-5 印刷需要予測からみた塗工紙の予測 (単位1, 000 トン, \%)

\begin{tabular}{c|c|c|c|c|c}
\hline 年 & 1987 & 1988 & 1990 & 1995 & 2000 \\
\hline 出版印刷 & $\begin{array}{c}510 \\
(100)\end{array}$ & $\begin{array}{c}526 \\
(103.1)\end{array}$ & $\begin{array}{c}560 \\
(109.8)\end{array}$ & $\begin{array}{c}600 \sim 720 \\
(117.6 \sim 120.0)\end{array}$ & $\begin{array}{c}670 \sim 720 \\
(131.4 \sim 141.2)\end{array}$ \\
\hline 商業印刷 & $\begin{array}{c}1,270 \\
(100)\end{array}$ & $\begin{array}{c}1,372 \\
(108.0)\end{array}$ & $\begin{array}{c}1,610 \\
(126.8)\end{array}$ & $\begin{array}{c}2,140 \sim 2,200 \\
(168.5 \sim 173.2)\end{array}$ & $\begin{array}{c}2,660 \sim 2,870 \\
(209.4 \sim 226.0)\end{array}$ \\
\hline 合 計 & $\begin{array}{c}1,780 \\
(100)\end{array}$ & $\begin{array}{c}1,898 \\
(106.6)\end{array}$ & $\begin{array}{c}2,170 \\
(121.9)\end{array}$ & $\begin{array}{c}2,740 \sim 2,810 \\
(153.9 \sim 157.9)\end{array}$ & $\begin{array}{r}3,330 \sim 3,590 \\
(187.0 \sim 201.7)\end{array}$ \\
\hline
\end{tabular}

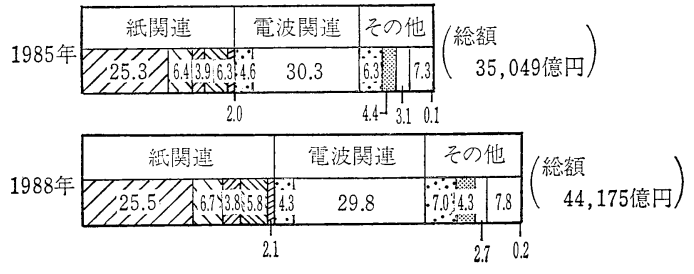

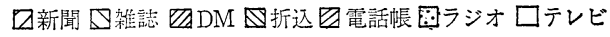

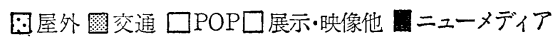

図-4 広告・包装に占める紙の地位一日本の 広告費と媒体別構成比(\%)-

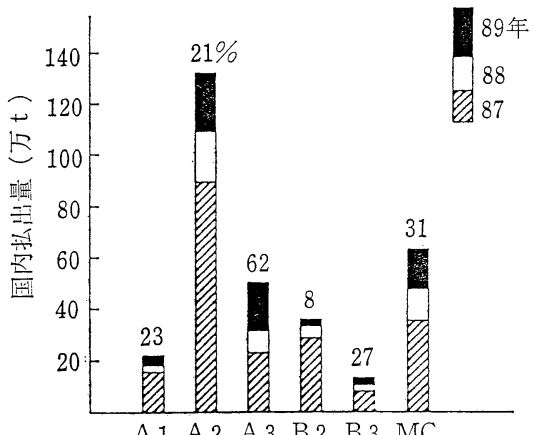

図-5 グレード別需要推移 1987〜89

いる。ここで，A 1，2，3 とは上質原紙をベースに片面 でそれぞれ $20,10,10 \mathrm{~g} / \mathrm{m}^{2}$ 以下の塗工液を塗布したも ので，B 1，2，3 とは中質原紙に上記と同じ量の塗布を 行ったもの, 微塗工紙とは上質, 中質の原紙に両面で $12 \mathrm{~g} / \mathrm{m}^{2}$ 程度の塗布を行ったものと規定されている。

このように軽量コート紙および微塗工紙が急増した理 由は, はじめに述べたように軽薄短小化の風潮に加えて 通信販売カタログととじ込み広告などの PR 用紙が急 増していることによるものである。

一方, 塗工板紙は塗工紙ほど目立った伸びはないが包
装材料の高級化志向などもあって着実な増加を示してい る。

以上，紙の種類と用途について本紙と関連の深い印刷 用紙をとりあげその最近の動向を示した。

\section{4. よ め}

紙は西暦 105 年中国で発明され当時のぼろ, 魚網など の原料から木材パルプを主原料として使い出したのがわ ずか 150 年前である。以来, 紙は社会文化の歯車の 1 つ として不可欠な材料として現在に到っている。一見不変 のように見える紙という材料も最近の高度成長と社会の 変貌に応じてその様相が少しずつ変わって来ている。

本稿はその一部をとらえご紹介した次第であるが，こ こに例示しなかった分野でも紙の用途はますます拡大し てゆく傾向にある。

このような变遷についての一端が本稿によって得られ れば幸いである。

\section{引用 文 献}

1）門屋 卓：紙ハ技協誌，33[4]，250（1979）

2) J. Clark : PPMC, Convention Issue (1943)

3) T. Pye, O. V. Washburn and J. G. Buchanan : Consolidation of The Paper Web, Vol.1, p. 355, B. P. B. I. F (1966)

4) 門屋, 角, 吉野 : 新紙の科学, p. 127, 中外産業調 査会 (1989)

5）塚谷，太田：紙パルプ技術タイムス，29, 11 (1986)

6) 門屋, 角, 吉野 : 前出 4)

7）例えば J.Casey : "Pulp \& Paper” A Wiley-Interscience Pub. (1981)

8）大野泰雄 : “特殊機能紙” p. 39〜 61, シーエムシ - (1984)

9）永井弘一, 藤平茂夫 : 紙パルプ技術タイムス, 増 刊号, p. 45 (1991) 